\title{
Chemodetection of the predatory seastar Leptasterias polaris by the whelk Buccinum undatum
}

\author{
Christian Harvey ${ }^{1}$, François-Xavier Garneau ${ }^{1}$, John H. Himmelman ${ }^{2}$ \\ ${ }^{1}$ Département des sciences fondamentales, Université du Québec à Chicoutimi, Chicoutimi, Québec G7H 2B1, Canada \\ ${ }^{2}$ Département de biologie et GIROQ, Université Laval, Québec G1K 7P4, Canada
}

\begin{abstract}
The behavioural response of the whelk Buccinum undatum L. to its predator, the seastar Leptasterias polaris Müller, was examined by quantifying the whelk's response to living seastars or water which had been exposed to a seastar, and to saponins extracted from seastars. Whelks detect the seastar by water-borne substances. Contact with seastars or water which had contained the seastar for a prolonged period $(3 \mathrm{~h})$ usually provoked contortions. The whelk showed no response to the nonpredatory seastar Henricia sp. Saponins extracted from the aboral surface, oral surface, cardiac stomach, and pyloric caecum of $L$. polaris all provoked defensive reactions which become stronger with increasing saponin concentration. The weakest response was from extracts from the pyloric caecum. In contrast to sexually mature whelks measuring $>7 \mathrm{~cm}$ in shell length, smaller immature whelks less frequently underwent contortions in response to $L$. polaris; rather, they rapidly attached to the substratum and fled. The development of a strong and reliable escape response (contortions) by large whelks probably permits them to associate more closely with large $L$. polaris and thus profit from abundant bivalve prey in deeper sediment bottom areas.
\end{abstract}

\section{INTRODUCTION}

Many studies indicate the importance of chemodetection in inter-and intra-specific interactions among marine benthic species (Feder 1967, Mackie et al. 1968, Grant \& Mackie 1974, Phillips 1978, Watanabe 1983), and the sensory organs involved can be highly discriminating. For predators, natural selection probably favours the ability to select prey which increase their fitness, whereas for prey species selection should favor the ability to avoid predators. In many habitats, certain prey species are absent because they lack adequate defenses against predators (Paine et al. 1985), while in other situations prey can coexist with predators due to anatomical or behavioural defenses (Feder 1963). Behavioural defenses act only when the predator is detected, in contrast to anatomical defenses, such as a protective shell, which act continuously (Edmunds 1974)

In marine benthic systems among the most well known predator-prey interactions involving behavioural responses are those between seastars and their prey. Many invertebrates, particularly molluscs, display escape responses to predatory seastars (Ansell 1969. Harvey 1985). The response has often been shown to be elicited by substances exuded into the water by the seastar (Grant \& Mackie 1974), and Mackie et al. (1968) show that the active substances secreted by 2 seastars were saponins, specifically steroid glycosides (Mackie \& Turner 1970).

In the present study, we examine the behavioural response of the whelk Buccinum undatum L. to the seastar Leptasterias polaris Müller. B. undatum, as well as being a prey of $L$. polaris, is a predator itself, and in the subtidal community in the northern Gulf of St. Lawrence, these are the 2 most important predators (Himmelman unpubl.). To examine the behavioural response of $B$. undatum to $L$. polaris we first study the response of whelks to living seastars, and secondly examine their response to different concentrations of saponins extracted from different tissues of $L$. polaris. Saponins from the aboral body wall, oral body wall, pyloric caecum, and cardiac stomach were isolated and characterized during a previous study (Harvey 1985). 


\section{METHODS}

The behavioural response of Buccinum undatum to Leptasterias polaris was examined during July and August 1982 in a laboratory at Havre-Saint-Pierre in the northern Gulf of St. Lawrence, eastern Canada. Whelks were collected daily in the afternoon (using baited traps), and maintained overnight in large tanks continually supplied with fresh seawater. Experiments were run the following day in standing water in plastic containers measuring $20 \times 17 \times 15 \mathrm{~cm}$ (4l). The response of each whelk was examined only once.

In the first series of experiments we examined the response of whelks measuring $>7 \mathrm{~cm}$ in shell length (which are sexually mature according to Martel et al. $1986 \mathrm{a}$, b) to direct contact with Leptasterias polaris, the whelk being placed on the central disc of an inverted seastar; to the presence of $L$. polaris; to water which had contained an L. polaris for $3 h_{i}$ and to direct contact with Henricia sp., a seastar which is not a predator of Buccinum undatum. Another series of experiments was made which examined the response of whelks measuring 2.6 to $6.5 \mathrm{~cm}$ (individuals with undeveloped gonads) to the presence of $L$. polaris and to water which had contained an $L$. polaris for $3 \mathrm{~h}$. For both series of experiments, a control experiment was performed in which whelks were simply transferred from one container to another. In each experiment 30 whelks were tested and the response was noted during a period of 5 min. The L. polaris used in these experiments measured 8 to $14 \mathrm{~cm}$ in diameter $($ mean $=10.2, \mathrm{SD}=1.53$, $\mathrm{n}=47$ ) and the Henricia measured 6 to $12 \mathrm{~cm}$ (mean $9.3, \mathrm{SD}=2.87, \mathrm{n}=3$ ). To compare response durations a t-test was used, whereas to compare the percentage of whelks displaying a specific response a t-test of arcsintransformed percentage values was employed (Sokal \& Rohlf 1969).

Saponins were isolated from Leptasterias polaris (measuring 14 to $28 \mathrm{~cm}$ in diameter) which had been collected in the field and frozen. After thawing, the oral and aboral surfaces, cardiac stomach and pyloric caecum were separated and homogenized. Then two $70 \%$ aqueous methanol extractions were made. To obtain a crude mixture of saponins, suspended material was removed by centrifugation, a benzene extraction was made of the supernatant, and the aqueous methanol layer was evaporated. The saponins were then adsorbed onto Amberlite XAD-2 resin and washed several times with water to remove inorganic salts. Finally, we performed low pressure liquid chromatography on silica gel (13 to $24 \mathrm{\mu m})$, using dichloromethane-methanol-water (60-19.4-3.4 v/v) as eluant. Elution was monitored by TLC and the saponins were obtained as a distinct group of products with an $R_{f}$ of 0.20 to 0.40 . Characterization was achieved by car- bohydrate analysis of the acid-hydrolyzed saponin mixture (xylose, galactose, quinovose and fucose) and by a TLC-blood detection method based on the hemolytic property of saponins (Yoon \& Wrolstad 1984).

To quantify the response of whelks to the saponins from different organs of the seastar, we applied them to the anterior part of the whelk's foot because Nielsen (1975) reported that this part is important in the whelk's chemodetection of prey, and because our preliminary tests showed it was the most sensitive part of the foot. While the siphon is also a site of chemoreception, it was not used in examining the response of whelks because it was always in motion. For each extract, $16 \mathrm{mg}$ were dissolved in $800 \mu \mathrm{l}$ of filtered seawater and dilutions were made to the desired concentrations. Prior to each test the whelk was left undisturbed for at least $10 \mathrm{~min}$ in a $4 \mathrm{l}$ container to allow it to resume normal behaviour. In testing each whelk, a $20 \mu \mathrm{l}$ volume of the desired extract at the desired concentration was applied at $\sim 3 \mathrm{~mm}$ from the anterior edge of the whelk's foot, and then the whelk's behaviour was observed for a period of $2 \mathrm{~min}$. The responses of 10 whelks (or less in some instances due to laboratory problems) were examined for each concentration of the saponins from each of the 4 tissues.

\section{RESULTS}

\section{Escape response of large whelks}

When a whelk was placed in contact with a Leptasterias polaris it displayed a characteristic gastropod escape behaviour. Its foot was extended raising the shell, the shell was then rotated from side to side, and finally it fell as it lost contact with the substratum. The detached foot became extended and the margins folded inward. The violent contortions separated the whelk from the seastar. In Expt 2 (Table 1), 29 out of 30 whelks (97\%) individually placed on an $L$. polaris responded with violent contortions. Mean reaction time (time to the beginning of the reaction) was only $0.2 \mathrm{~min}$ and within a mean of 1.1 min the whelks returned to normal position, attached to the substratum. The whelk which did not respond with contortions entered its shell during the transfer and remained there throughout the 5 min observation period. By contrast, in Expt 1 where whelks were simply transferred from one container to another, only 1 of 30 whelks $(3 \%)$ displayed contortions, significantly less than in Expt $2(p<0.01)$, and the mean time to return to normal attached position was $2.0 \mathrm{~min}$, significantly greater $(p<0.01$ ) than in Expt 2 (Table 1). Thus, contact with L. polaris almost always provoked a strong escape response which was followed by a rapid attachment to the substratum. 
Table 1. Buccinum undatum. Behavioural response to the seastars Leptasterias polaris and Henricia sp.

\begin{tabular}{|c|c|c|c|c|c|c|c|}
\hline \multirow{2}{*}{$\begin{array}{l}\text { Experimental } \\
\text { treatment }\end{array}$} & \multirow{2}{*}{$\begin{array}{c}\text { Remained } \\
\text { inside shell } \\
n / 30\end{array}$} & \multirow{2}{*}{$\begin{array}{c}\text { Normal } \\
\text { behaviour } \\
n / 30\end{array}$} & \multirow{2}{*}{$\begin{array}{l}\text { Only agitated } \\
\text { behaviour } \\
n / 30\end{array}$} & \multicolumn{3}{|c|}{ Contortion behaviour } & \multirow{2}{*}{$\begin{array}{l}\text { Time to attach } \\
\text { ment to substra } \\
\text { tum }[\text { min }(S D ; n)\end{array}$} \\
\hline & & & & $\mathrm{n} / 30$ & $\begin{array}{l}\text { Reaction time } \\
{[\text { [min (SD)] }}\end{array}$ & $\begin{array}{l}\text { Reaction dura- } \\
\text { tion }\{\text { min (SD)] }\end{array}$ & \\
\hline \multicolumn{8}{|c|}{ Experiments with sexually mature Buccinum undatum $(7.0$ to $10.2 \mathrm{~cm}$ in length) } \\
\hline $\begin{array}{l}\text { 1. Simple transfer of } \\
\text { whelk from one con- } \\
\text { tainer to another } \\
\text { (control) }\end{array}$ & 4 & 25 & 0 & 1 & 1.33 & 0.72 & $1,99(0.24 ; 26)$ \\
\hline $\begin{array}{l}\text { 2. Whelk placed on } \\
\text { L. polaris }\end{array}$ & 1 & 0 & 0 & 29 & $0.21(0.05)$ & $0.45(0.08)$ & $1.10(0.24 ; 28)^{\bullet}$ \\
\hline $\begin{array}{l}\text { 3. L. polaris placed } \\
\text { with whelk (no con- } \\
\text { tact) }\end{array}$ & - & 8 & 19 & 3 & $1.16(1.53)$ & $1.63(1.06)$ & $1.63(1.06 ; 3)^{\cdots}$ \\
\hline $\begin{array}{l}\text { 4. Whelk placed in } \\
\text { water previously ex- } \\
\text { posed to L. polaris }\end{array}$ & 1 & 4 & 3 & 22 & $0.30(0.15)$ & $0.77(0.24)$ & $1.19(0.71 ; 28)^{\circ}$ \\
\hline $\begin{array}{l}\text { 5. Whelk placed on } \\
\text { Henricia sp. }\end{array}$ & 7 & 21 & 0 & 2 & $1.71(3.61)$ & $0.51(0.9)$ & $2.46(0.45 ; 23)$ \\
\hline \multicolumn{8}{|c|}{ Experiments with small sexually immature Buccinum undatum (2.6 to $6.5 \mathrm{~cm}$ length) } \\
\hline $\begin{array}{l}\text { 6. Simple transfer of } \\
\text { whelk from one con- } \\
\text { tainer to another } \\
\text { (control) }\end{array}$ & 8 & 20 & 0 & 1 & 0.01 & $>5.00$ & $1.63(0.48 ; 20)^{\circ}$ \\
\hline $\begin{array}{l}\text { 7. L. polaris placed } \\
\text { with whelk (no con- } \\
\text { tact) }\end{array}$ & - & 8 & 18 & 4 & $1.93(1.73)$ & $0.70(0.28)$ & $0.70(0.28 ; 4) \cdots$ \\
\hline $\begin{array}{l}\text { 8. Whelk placed in } \\
\text { water previously ex- } \\
\text { posed to L. polaris }\end{array}$ & 0 & 8 & 11 & 11 & $0.26(0.10)$ & $0.51(0.13)$ & $0.88(0.66 ; 30)$ \\
\hline \multicolumn{8}{|c|}{$\begin{array}{l}\text { - One whelk which did not return to normal position (attached to the substratum) within } 5 \text { min was not included in the } \\
\text { calculation of the time to attachment to substratum } \\
\text { Experiment began with whelks attached to substratum, and the time to attachment to substratum is for those individuals } \\
\text { which underwent contortions and detached, and then reattached to the substratum }\end{array}$} \\
\hline
\end{tabular}

\section{Chemical nature of stimulus}

In Expt 3, when a Leptasterias polaris was placed several centimeters from a whelk which was attached to the substratum and had been left undisturbed for at least 10 min (no contact between the whelk and seastar was permitted), only 3 out of 30 whelks displayed contortions (Table 1). However, 19 other whelks became agitated, turning their shell left and right but not detaching from the substratum. Thus, $22(19+3)$ out of 30 whelks tested $(73 \%)$ showed a defensive reaction, significantly more $(\mathrm{p}<0.01)$ than in the control experiment (Expt 1). In Expt 4 (Table 1) when whelks were placed into a $4 \mathrm{l}$ container of seawater in which there had been a seastar for a $3 \mathrm{~h}$ period, the number of whelks displaying a defensive reaction $3+$ 22) was similar to that in Expt $3(p>0.05)$. However, significantly more whelks displayed contortions than in Expt 3 (22/30 compared to 3/30; $\mathrm{p}<0.01)$, although less $(p<0.01)$ than in Expt 2, where there was direct contact with $L$. polaris. The duration of the contortions in
Expt 4 was significantly longer $(p<0.05$ ) than in Expt 2 , but the reaction time and time to return to normal were similar $(p>0.05)$. Expts $3 \& 4$ demonstrated that whelks detect $L$, polaris by water-borne substances released by L. polaris. In both Expts 3 \& 4 the escape response terminated in 1.2 to $1.6 \mathrm{~min}$ and was not repeated. This suggests that during predator-prey interactions in nature, violent contortions are used once for escaping from a predator. After this further violent contortions might not be useful. Probably the reduced response in Expt 3, compared to Expt 4, was due to a lower concentration of substances emitted by the seastar.

\section{Specificity of seastar detection}

To examine the hypothesis that whelks can identify their predators, in Expt 5 we measured their response to Henricia sp., a seastar which is a grazer of sponges and other sessile organisms rather than a predator of mobile species (Table 1 ). Only 2 out of $30(7 \%)$ of the 
whelks placed on the oral side of Henricia displayed a defensive response, significantly less $(p<0.01)$ than in Expt 2, and similar to ( $p>0.05)$ Expt 1 in which whelks were simply transferred between containers. Further, the time to return to the normal attached position in Expt 5 was more than twice as long as in Expt 2 ( $p$ $<0.01)$ and similar $(p>0.05)$ to that in Expt 1. Thus, Buccinum undatum clearly distinguished between the non-predatory Henricia and the predatory L. polaris.

\section{Variation in escape response of whelks with size}

Expts 6,7 and 8 performed on Buccinum undatum measuring 2.6 to $6.5 \mathrm{~cm}$ in shell length gave results similar to Expts 1 to 5 , where the whelks measured 7.0 to $10.2 \mathrm{~cm}$ (Table 1). In Expt 8, individuals placed in water which had contained Leptasterias polaris more frequently displayed contortions ( $p<0.01$ ), and the time to return to the normal attached position was significantly shorter $(p<0.01)$ than in Expt 6 in which whelks were only manipulated. Further, in Expt 7 when an L. polaris was introduced into a container with an undisturbed whelk (without contact between the whelk and seastar), a defensive reaction (agitation + contortions) was significantly more frequent $(p<0.01)$ than in the control experiment (Expt 6). However, differences between small and large whelks were apparent. When whelks were placed in 'L. polarisscented' water, small whelks less frequently ( $p<0.01$ ) displayed contortions (37\%, Expt 8) than large whelks $(87 \%$, Expt 4), and the time to return to the normal position was significantly shorter $(p<0.05)$ for small whelks. Thus, while both small and large whelks show the ability to detect $L$. polaris by means of water-borne substances, large individuals are more likely to display violent contortions involving detachment from the substratum, and small whelks more rapidly attach themselves to the substratum.

\section{Response of whelks to saponins extracted from Leptasterias polaris}

We further examined the response of whelks to varying quantities of saponins which had been extracted from the oral surface, aboral surface, cardiac stomach and pyloric caecum of Leptasterias polaris (Table 2). A general pattern was evident for the 4 types of saponin extracts. At the lowest concentrations most individuals showed no response at all, or a weak and localized response at the site of application at the anterior part of the foot. As the concentration increased stronger responses were observed, first a transmission of the reaction posteriorly along the foot, and then the lifting of the foot by $1 \mathrm{~cm}$ or more (sometimes the anterior part of the foot became folded under the shell). Finally, falling due to loss of contact with the substratum and in a few instances contortions were observed. Contortions occurred only at concentrations of 200 or $400 \mu \mathrm{g}$ $(20 \mu l)^{-1}$. The latter responses were most frequent for the extract from the aboral surfaces, oral surfaces and cardiac stomach, and least frequent for saponins from the pyloric caecum. Fleeing (a change in direction and increase in speed) often followed the initial reaction to the extracts, and contrary to the other behaviours, there was no increase in frequency of fleeing whelks with increasing concentration ( $\chi^{2}$ test, $\mathrm{p}<0.05$ ). However, the fleeing response was significantly more frequent ( $p$ $<0.05)$ with extracts from the aboral $(54 \% ; n=100)$ and oral $(51 \%, \mathrm{n}=97)$ surfaces, than with extracts from cardiac stomach (37\%; $\mathrm{n}=99)$ and pyloric caecum $(27 \% ; n=89)$.

\section{Duration of foot-raising response in relation to saponin concentration}

Following a square root transformation to normalize the data, a linear increase in the duration of the footraising response was observed with increasing saponin concentration from 5 to $400 \mu \mathrm{g}(20 \mu \mathrm{l})^{-1}$ (Fig. 1). For the saponins from the 4 tissues the correlation coefficient was highly significant ( $p<0.001$ ). There was considerable overlap in the results of the bioassays with the saponins for the various tissues. An analysis of covariance indicated that the only significant difference among the relations was that regression line for the saponins from the oral surface had a significantly greater slope $(p<0.05)$.

\section{DISCUSSION}

Our results demonstrate that Buccinum undatum perceives its predator, the seastar Leptasterias polaris, by distance chemodetection, and that saponins from 4 different tissues of $L$. polaris provoke the defensive response from the whelk. These results concord with those of Mackie et al. (1968) on the response of $B$. undatum to 2 other predatory seastars, Asterias rubens and Marthasterias glacialis. While Henricia sp. also contain saponins (Burnell 1978), the lack of a response to contact with this non-predator of $B$. undatum, in our study and previous studies (Mackie et al. 1968), demonstrates that the whelk can identify the saponins of its predators. Thomas \& Gruffydd (1971), Phillips (1976), and Watanabe (1983) report other instances of molluscan prey which specifically respond to substances released by their predators. Phillips $(1975,1978)$ 
Table 2. Buccinum undatum. Response of whelk to different concentrations of saponins from different tissues of the seastar Leptasterias polaris. Values are numbers of whelks reacting in each way at each concentration

\begin{tabular}{|c|c|c|c|c|c|c|c|c|c|c|}
\hline \multirow[t]{2}{*}{ Type of reaction } & \multicolumn{10}{|c|}{ Concentration $\left(\mu \mathrm{g}[20 \mu \mathrm{l}]^{-1}\right)$} \\
\hline & 0.5 & 1.0 & 2.5 & 5.0 & 10 & 25 & 50 & 100 & 200 & 400 \\
\hline \multicolumn{11}{|l|}{ Aboral surface } \\
\hline No response & 3 & 2 & 1 & 1 & & & & & & \\
\hline Localized reaction & 6 & 6 & 5 & 1 & 1 & 1 & 1 & & 1 & 2 \\
\hline Reaction passed posteriorly & & & 1 & 6 & 4 & 5 & 2 & 1 & 3 & \\
\hline Lifting of $\mathrm{foot}>1 \mathrm{~cm}$ & 1 & 2 & 3 & 2 & 5 & 3 & 6 & 8 & 5 & 2 \\
\hline Fall due to detachment & & & & & & 1 & 1 & 1 & & 4 \\
\hline Strong contortion & & & & & & & & & 1 & 2 \\
\hline \multicolumn{11}{|l|}{ Oral surface } \\
\hline No response & 2 & 3 & & & & 1 & & & 1 & \\
\hline Localized reaction & 8 & 6 & 3 & 7 & & 2 & 2 & & & \\
\hline Reaction passed posteriorly & & & 3 & 2 & 2 & 3 & 2 & 2 & & \\
\hline Lifting of foot $>1 \mathrm{~cm}$ & & 1 & 4 & 1 & 6 & 4 & 4 & 8 & 7 & 7 \\
\hline $\begin{array}{l}\text { Fall due to detachment } \\
\text { Strong contortion }\end{array}$ & & & & & & & 1 & & 2 & 3 \\
\hline \multicolumn{11}{|l|}{ Cardiac stomach } \\
\hline No response & 6 & 6 & 2 & 3 & 3 & & 1 & & & \\
\hline Localized reaction & 3 & 4 & 5 & 5 & 3 & 4 & 3 & & 2 & \\
\hline Reaction passed posteriorly & & & & 1 & 1 & 1 & 1 & 1 & 1 & \\
\hline Lifting of foot $>1 \mathrm{~cm}$ & 1 & & 3 & 1 & 2 & 5 & 5 & 8 & 5 & 7 \\
\hline Fall due to detachment & & & & & & & & 1 & 1 & 2 \\
\hline Strong contortion & & & & & & & & & 1 & 1 \\
\hline \multicolumn{11}{|l|}{ Pyloric caecum } \\
\hline No response & 10 & 7 & 5 & 2 & 1 & 1 & & & & \\
\hline Localized reaction & & 2 & 4 & 7 & 5 & 6 & 7 & 5 & & \\
\hline Reaction passed posteriorly & & & & & 1 & 2 & 1 & 1 & & 2 \\
\hline Lifting of foot $>1 \mathrm{~cm}$ & & & & & & 1 & 2 & 4 & 3 & 8 \\
\hline Fall due to detachment & & & & & & & & & 1 & \\
\hline Strong contortion & & & & & & & & & & \\
\hline
\end{tabular}

suggests that the ability of the whelk and other species to distinguish their predators from non-predators prevents wasteful expenditures of energy.

The response of Buccinum undatum increases with the degree of exposure to Leptasterias polaris (Tables 1 \& 2; Fig. 1) and other predatory seastars (Mackie et al. 1968). When purified saponins were applied near the anterior part of the whelk's foot, contortions were only elicited 0 to $15 \%$ of the time at concentrations of $200 \mu \mathrm{g}$ $(20 \mu \mathrm{l})^{-1}$ or greater, and the response became progressively weaker with decreasing saponin concentration (Table 2; Fig. 1). When exposed to water in which a seastar had been kept for several hours, $77 \%$ of whelks responded with contortions, while virtually all individuals responded with contortions to direct contact with L. polaris (Table 1). This progression is probably analogous to the whelk's response to $L$. polaris at decreasing distances. At weak saponin concentrations, or great distance from the seastar, the response is weak and mainly a fleeing or change of direction, and this response is highly variable (Table 2). Under strong chemical stimulus, as when being placed in water in which a seastar has been present for several hours, the response is much stronger, and, when there is contact with a predatory seastar, was invariably violent contortions. The absolute difference between the responses to purified saponins and those to 'L. polaris-scented' water or to contact with $L$. polaris may also indicate that $B$. undatum detects other substances released by $L$. polaris.

Our previous study (Harvey 1985) showed that the total saponin content was several times greater in the cardiac stomach (5.53 $\mathrm{mg} \mathrm{g}^{-1}$ wet weight) than in the oral surface, aboral surface, and pyloric caecum (1.35, 1.15, and $1.25 \mathrm{mg} \mathrm{g}^{-1}$ wet weight, respectively). Further, there were similar proportions of different types of saponins in oral and aboral surfaces. The pyloric caecum showed marked differences and the cardiac stomach was intermediary. In our bioassays examining the response of whelks to extracts from the various tissues, the only result which corresponds to the chemical comparisons is the difference between the pyloric caecum and the other tissues. The lack of a response to Henricia sp. (Table 1) demonstrates that the whelk's response is specific to its predators.

Previous studies on the response of molluscs to 

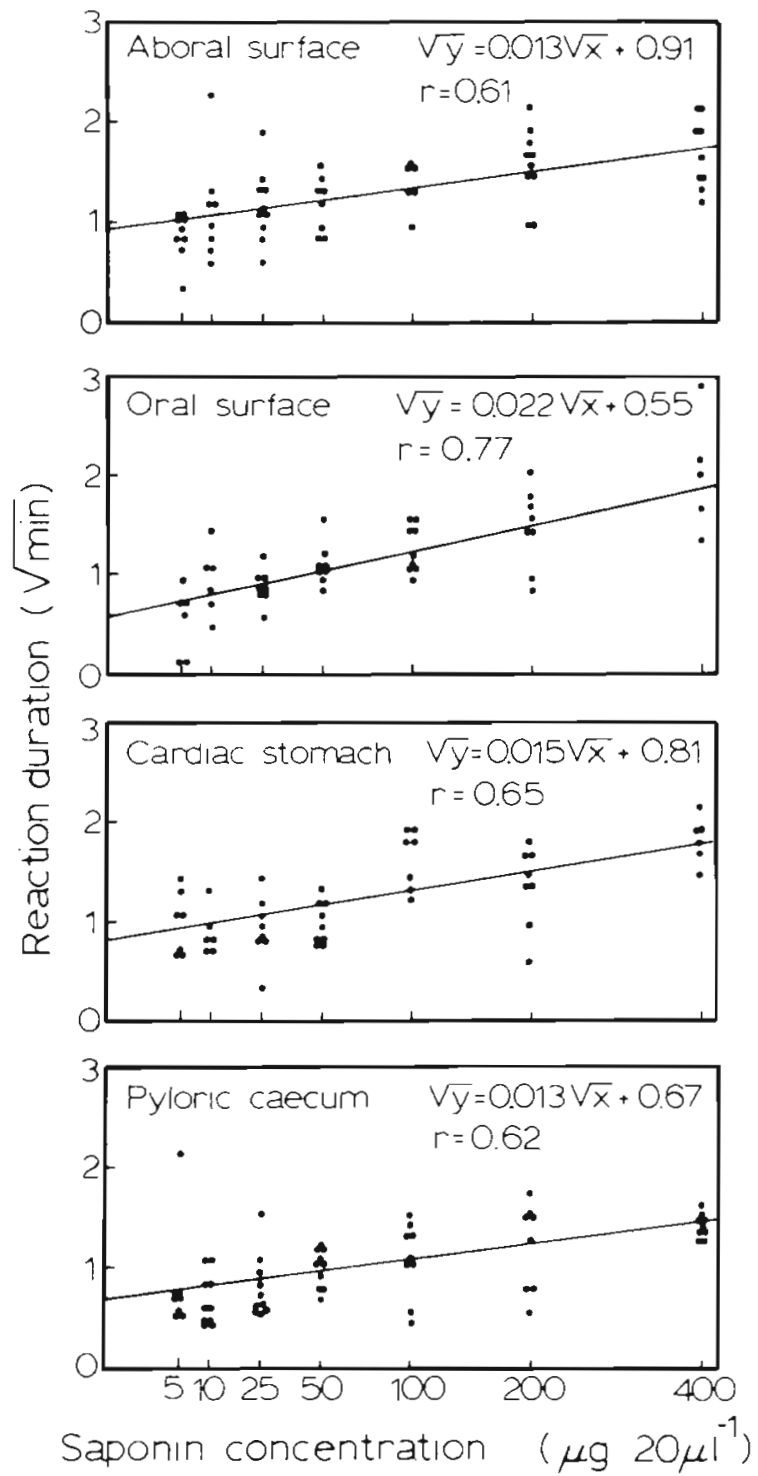

Fig. 1. Buccinum undatum. Relation between duration of footraising response of the whelk and saponin concentration, for saponins extracted from 4 tissues of the seastar Leptasterias polaris. In each determination, a $20 \mu \mathrm{l}$ volume of extract at the desired concentration was applied $\sim 3 \mathrm{~mm}$ from the anterior edge of the whelk's foot. A square root transformation has been made of both variables

predatory seastars show the strongest response to extracts from external surfaces, particularly the podia, or from the cardiac stomach (Feder \& Arvidsson 1967. Thomas \& Gruffydd 1971, Mayo \& Mackie 1976, Phillips 1978). However, the responses to saponins from different tissues of Leptasterias polaris did not differ notably. There was possibly a decreased response to saponins from the pyloric caecum. Barbier (1976) observed no response of Nasarius fossata to saponins from the pyloric caecum of its predator, Pisaster brevispinus. In our study, violent contortions were only elicited in at most $15 \%$ of the Buccinum undatum tested with saponins from $L$. polaris at concentrations of 200 to $400 \mu \mathrm{g}(20 \mu \mathrm{l})^{-1}$, whereas, from studies in Scotland, Mackie et al. (1968) indicate that violent contortions are the usual response of $B$. undatum to saponins at concentrations of 400 to $500 \mu \mathrm{g}(20 \mu \mathrm{l})^{-1}$ from Asterias rubens and Marthasterias glacialis.

Selective forces may act in opposite directions in the evolution of defensive behaviours (Phillips 1975). The development of an effective escape behaviour increases the prey's survival, but an overly defensive behaviour may prevent a prey species from using the same habitats as its predators, a factor which could exclude it from important food resources. Thus, prey species probably achieve greatest fitness when their predator-avoidance behaviours are developed to some intermediate level. An intermediate type of response would seem to be particularly advantageous for Buccinum undatum because of its general sympatry with Leptasterias polaris and because it preys on bivalves (Nielsen 1975), which are also important prey of L. polaris (Himmelman unpubl.). Phillips (1975) suggests that a variable response to a predator, as we observed for $B$. undatum to weaker concentrations of saponins (Table 2), is a reflection of selective forces acting in opposite directions. There may be seasonal variations in a prey's escape response to adjust to variations in such factors as the seasonal feeding activity of the predator, or to availability of other prey to the predator (Landenberger 1968, Paine 1969). A decreased response to $L$. polaris during the autumn through later winter might be advantageous for $B$. undatum, since female $L$. polaris spend this period brooding their young rather than feeding (Boivin et al. 1986). This hypothesis is supported by the observation of Martel et al. (1986a) that the feeding activity of $B$. undatum is markedly increased during the winter.

The difference we observed between the response of smaller whelks ( 3 to $7 \mathrm{~cm}$ in length, sexually immature) compared to larger whelks (>7 cm, sexually mature) may represent fine adjustments related to their degree of contact with Leptasterias polaris in the subtidal zone (Doering \& Phillips 1983). There is some partitioning of different sized whelks and seastars in different habitats (Jalbert et al. unpubl.). Whelks measuring 3 to $7 \mathrm{~cm}$ in length are most common on rocky bottoms (bedrock, boulders and cobbles), while $>7 \mathrm{~cm}$ whelks are concentrated on sediment bottoms. Similarly, small $L$. polaris (5 to $20 \mathrm{~cm}$ in diameter) are strongly concentrated on bedrock and boulder substrates whereas large individuals $(>20 \mathrm{~cm}$ ) are most often found on gravel and sand. The main defenses of small whelks (which are in greatest contact with small seastars) against $L$, polaris appear to be detection at distance and fleeing. Small whelks may be highly vulnerable to 
seastars once there is contact. Predators also use chemoreception in detecting and finding their prey, and Ansell (1969) and Doering (1976) hypothesize that the rate of emission of substances by the prey is related to their degree of activity. If this is true, violent contractions might increase the vulnerability of small whelks to seastars. For whelks measuring $<4 \mathrm{~cm}$ in shell length, even a running response may not be an effective defense, as Jalbert et al. (unpubl.) note a drop in the frequency of whelks between 2 and $4 \mathrm{~cm}$ in shell length which they suggest is due to mortality from seastar predation. In contrast to small whelks, large individuals consistently display violent contortions when placed in contact with $L$. polaris. We hypothesize that the ability of large whelks to free themselves from seastars using forceful contortions permits them to coexist with large seastars and thus profit from abundant bivalve prey in the deeper sediment zone. While diving we have noted Buccinum undatum eating prey remains left by large L. polaris (unpubl. obs.).

Acknowledgements. We are indebted to Jean-Luc Simard for his tremendous aid with the extraction and characterization of the saponins, to Yves Boivin for his help in collecting the seastars for the chemical analyses, and to Helga Guderley for comments on the manuscript. A scholarship to Christian Harvey from PAIR (Programme d'aide institutionnelle à la recherche) is gratefully acknowledged. The project was supported by grants from MAIN (Ministère des Affaires indienne et du Nord), MEQ-FCAR (Ministère de l'éducation du Québec), and FUQAC (Fondation de l'Université du Québec à Chicoutimi) to F.-X. Garneau and from an NSERC grant to J. H. Himmelman.

\section{LITERATURE CITED}

Ansell, A. D. (1969). Defensive adaptations to predation in the molluscs. Proc. mar biol. Ass. India, Symp. Ser. 3: $487-512$

Barbier, M. (1976). Introduction à l'écologie chimique. Masson, Paris

Boivin, Y., Larrivée, D., Himmelman, J. H. (1986). Reproductive cycle of the subarctic brooding asteroid Leptasterias polaris. Mar. Biol. 92: 329-337

Burnell, J. (1978). Investigations of the steroidal components of the squid, Illex illecebrosus, and the starfish, Asterias vulgaris. M. Sc. thesis, Carleton University, Ottawa

Doering, P. H. (1976). A burrowing response of Mercenaria mercenaria elicited by Asterias forbesi. Veliger 19: $167-175$

Doering, P. H., Phillips, D. W (1983). Maintenance of the shore-level size gradient in marine snail Tegula funebralis (A. Adams): importance of behavioral responses to light and sea star predators. J. exp. mar Biol. Ecol. 67: $159-173$

Edmunds, M. (1974). Defense in animals, a survey of antipredator defenses. Longman, Harlow, U. K

Feder, H. M. (1963). Gastropod defensive response and their effectiveness in reducing predation by starfish. Ecology $44: 505-512$
Feder, H. M. (1967). Organisms responsive to predatory seastars. Sarsia 29: 271-394

Feder, H. M., Arvidsson, J. (1967). Studies on a sea-star (Marthasterias glacialis) extract responsible for avoidance reactions in a gastropod (Buccinum undatum). Ark. Zool. 19: $369-379$

Grant, P. T., Mackie, A. M. (1974). Interspecies and intraspecies chemoreception by marine invertebrates. In Grant, P. T., Mackie, A. M. (ed.) Chemoreception in marine organisms. Academic Press, New York, $p$. $105-140$

Harvey, C. (1985). Analyse chimique des astérosaponines chez Leptasterias polaris et leur rôle dans la réponse défensive de Buccinum undatum. M. Sc. thesis, Université du Québec à Chicoutimi

Landenberger, D. E. (1968). Studies on selective feeding in the Pacific starfish Pisaster in southern California. Ecology 49: $1062-1075$

Mackie, A. M., Lasker, R., Grant, P. T. (1968). Avoidance reactions of a mollusc Buccinum undatum to saponin-like surface-active substances in extracts of the starfish Asterias rubens and Marthasterias glacialis. Comp. Biochem. Physiol. 26: 415-428

Mackie, A. M., Turner, A. B. (1970). Partial characterization of a biologically active steroid glycoside isolated from the starfish Marthasterias glacialis. Biochem. J. 117: 543-550

Martel, A. Larrivée, D. H., Himmelman, J. H. (1986a). Reproductive cycle and seasonal feeding activity of the neogastropod Buccinum undatum. Mar. Biol. 92: 211-221

Martel, A., Larrivée, D. H., Himmelman, J. H. (1986b). Behaviour and timing of copulation and egg laying in the neogastropod Buccinum undatum. J. exp. mar. Biol. Ecol 96: $27-42$

Mayo, P., Mackie, A. M. (1976). Studies of avoidance reactions in several species of predatory British seastars. Mar Biol. 38: 41-49

Nielsen, C. (1975). Observations on Buccinum undatum attacking bivalves and on prey responses with a short review on attack methods of other prosobranchs. Ophelia 13: $87-108$

Paine, R. T (1969). The Plsaster-Tegula interaction: prey patches, predator food preference, and intertidal community structure. Ecology 50: 950-961

Paine, R. T., Castillo, J. C., Cancino, J. (1985). Perturbation and recovery of starfish-dominated intertidal assemblages in Chile, New Zealand, and Washington State. Am. Nat. 125: 679-691

Phillips, D. W. (1975). Distance chemoreception-triggered avoidance behavior of the limpet Acmaea (Collisella) limatula and Acmaea (Notoacmea) scutum to the predatory starfish Pisaster ochraceus. J. exp. Zool. 1914 199-209

Phillips, D. W. (1976). The effect of a species-specific avoidance response to predatory starfish on the intertidal distribution of two gastropods. Oecologia (Berl.) 23: 83-94

Phillips, D. W. (1978). Chemical mediation of invertebrate defensive behaviors and the ability to distinguish between foraging and inactive predators. Mar. Biol. 49 $237-243$

Sokal, R. R., Rohlf, F. J. (1969). Biometry. The principles and practice of statistics in biological research. W. H. Freeman, San Francisco

Thomas, S. E., Gruffydd, D. (1971). The types of escape reactions elicited in the scallop Pecten maximus by selected sea-star species. Mar. Biol. 10: 87-93 
Watanabe, J. M. (1983). Anti-predator defenses of three kelp forest gastropods: contrasting adaptations of closely related prey species. J. exp. mar. Biol. Ecol. 71: 257-270
Yoon, K. R., Wrolstad, R. E. (1984). Investigation of Marion blackberry, strawberry and plum fruit for the presence of saponins. J. Agric. Food Chem. 32: 691-693

This article was presented by Professor R. L. Haedrich; it was accepted for printing on June 9, 1987 